\title{
Colonic perforation due to the migration of an intrauterine device (IUD): surgical management for acute abdomen
}

\section{Rahim içi araç (RIA) migrasyonuna bağlı kolon perforasyonu: akut abdomenin cerrahi yönetimi}

\author{
Emre Günakan ${ }^{1}$, Hakan Buluş², Fatih Polat ${ }^{2}$ \\ ${ }^{1}$ University of Medical Sciences Keçioren Training and Research Hospital, Department of Obstetrics and Gynecology, Ankara, Turkey \\ ${ }^{2}$ University of Medical Sciences Keçioren Training and Research Hospital, Department of General Surgery, Ankara, Turkey \\ Geliş Tarihi: 24.04.2017 \\ Kabul Tarihi: 01.06.2017 \\ Doi:10.21601/ortadogutipdergisi.308450
}

\begin{abstract}
Intrauterine devices (IUDs) are frequently used,reversible and feasible contraception method. Wepresent a case involving a serious complication caused by anIUD and discuss this case with reference to the published literature.

A 30 year-old woman with 3 parities with a copper IUD for 3 years was evaluated for anacute abdomen, vaginal dischargeand $\mathrm{a} 38.8^{\circ} \mathrm{C}$ fever.Laboratory tests revealed elevation of white blood count and C-reactive protein (CRP). Radiologically, the IUD was seen to be localised outside the borders of the endometrial cavity, and bilateral complicated hyperintense pelvic masses were evident. Subsequently, the patient underwent a diagnostic laparotomy. A frozen pelvis caused by a pelvic abscess was revealed. The underlying reason for this was the IUD that had migrated to the rectosigmoid junction, resulting in a perforation. Subtotal hysterectomy, left salphingooophorectomy and loop colostomy were performed.After 10 days of follow-up, the patient was discharged without any further complication. IUDs represent an easily applicable contraceptive method with low complication rates. However, over along term, an IUD may cause inflammatory disorders and disturb the integrity of the uterus. Migration into the abdominal cavity is a serious IUD complication that physicians should be aware of, particularly in patients with abdominal pain.
\end{abstract}

Keywords: Colonic perforation, complication, intrauterine device, IUD

\section{Öz}

Rahim içi araç(RİA) sık kullanılan makul ve geri dönüşümlü bir kontrasepsiyon yöntemidir. Çalışmamızın amacı RİA'ya bağlı ciddi bir komplikasyonu literature tartışması eşliğinde sunmaktır.

Otuz yaşında 3 paritesi olan ve 3 yıldır bakırlı RİA'sı olan kadın akut abdomen, vajinal akıntı ve $38.8^{\circ} \mathrm{C}$ ateş ile değerendirildi. Laboratuvar testlerinde C-Reaktif Protein ve beyaz küre yüksekliği mevcuttu. Radyolojik olarak, endometrial kavite sınırları dışında RİA ve bilateral komplike hiperintens pelvik kitleler rapor edildi. Hastaya diagnostik laparatomi yapıldı. Pelvik apseye bağlı frozen pelvis durumu olduğu gözlendi. Altta yatan nedenin ise rektosigmoid bileşkeye migrate olan ve perforasyona sebep olan RİA olduğu saptandı. Hastaya subtotal histerektomi, sol salfingoogforektomi yapılıp ve loop kolostomi açıldı. 10 günlük takibin ardından hasta komplikasyonsuz taburcu edildi.

RİA düşük komplikasyon oranıla kolay uygulanabilir bir kontraseptif yöntemdir. Uzun dönemde inflamatuvar durumlara yol açarak uterus bütünlüğünü bozabilir. Abdominal kaviteye migrasyon karın ağrısı olan hastalarda özellikle akılda tutulması gereken ciddi bir RİA komplikasyonudur.

Anahtar Kelimeler: Kolon perforasyonu, komplikasyon, rahim içi araç, RIA 
Rahim içi araç (RiA) migrasyonuna bağlı kolon perforasyonu: akut abdomenin cerrahi yönetimi

\section{Indroduction}

Intrauterine device (IUD) is one of the most common contraception methods, and itwas first described by Richter in 1909. This method of contraception is associated with a global rate of approximately $14.3 \%$ [1]. IUDs are feasible, easily placed, reversible, cost-effective and as effective as surgical methods. Usually, IUDs are well tolerated but may be associated with occasional side effects such as pain, abnormal bleeding or complications, such as uterine perforation during placement. Uterine perforation usually occurs during insertion and occurs in approximately1.1-1.4 in 1000 procedures [2]. Removal of an IUD via the vagina may be an adequate treatment for complications such as abnormal vaginal bleeding or inflammatory disorders. However, IUDs may cause serious complications including intra-adominal organ perforation following uterine perforation. Laparoscopy, hysteroscopy, colonoscopy and laparotomy are all potential options for the surgical management of IUD migration. Here we present a case of acute abdomen complicated with colonic perforation and pelvic abscess that is treated with laparotomy. Our aim is to share our experience with a review of the relevant literature.

\section{Case Presentation}

A 30year-old woman with 3 parities who had been fitted with a copper IUD for 3 years presented to a town hospital's emergency room with abdominal pain and foul-smelling vaginal discharge. She had fever and pelvic pain for the previous 15 days. Pelvic tenderness and rebound were evident, and she had fever with a temperature of $38.8^{\circ} \mathrm{C}$. Laboratory tests revealed a range of abnormal results: white blood count (WBC), 12200/ml (4300/ml-10300/ $\mathrm{ml}$ ); sedimentation, $82 \mathrm{~mm} /$ hour (0-20 mm/hour); C-reactive protein (CRP), $12.6 \mathrm{mg} / \mathrm{dl}(0-0.8 \mathrm{mg} / \mathrm{dl})$; fibrinogen, $801 \mathrm{mg} / \mathrm{dl}(203-472 \mathrm{mg} / \mathrm{dl})$ and Ca 125, 79.9 (0-35 U/ml). In first step ultrasonography (US), we detected multiseptic lobulated bilateral adnexal cysts (diameters: $110 \times 75 \mathrm{~mm}$ on theleft and $65 \times 60 \mathrm{~mm}$ on theright) with hyperintense content. Moreover, we observed an IUD that was localised outside of the borders of the endometrial cavity. In light of these findings, the patient was transferred to our tertiary centre with a differential diagnosis of possible ovarian malignancy, serous cystadenoma or intraabdominal abscess.

After gynaecological examination, we performed emergent magnetic resonance imaging (MRI). A suspicious irregularity was noted in the fundal part of the endometrial cavity (Figures 1 and 2), comprising right adnexal $66 \times 92 \mathrm{~mm}$ and left adnexal $33 \times 51 \mathrm{~mm}$ septate, lobular contoured, thick-walled masses that were heterogenous hypointense in T1A sequences and hyperintense in T2A sequences compared to muscle.
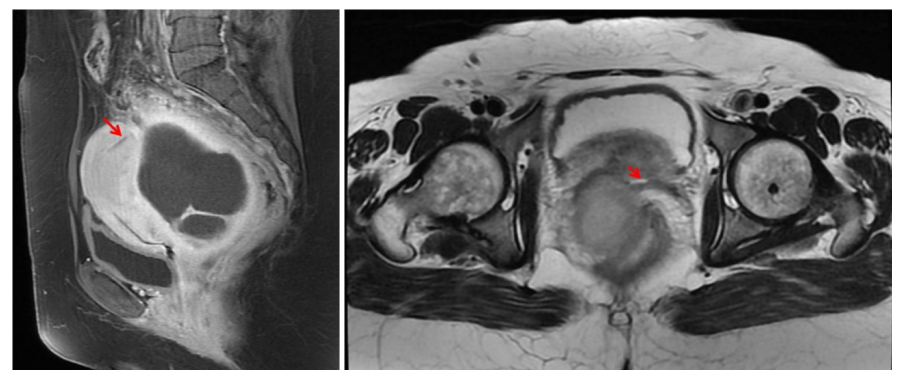

Figures 1 and 2. The uterine perforation line through the myometrium. Image of the T-part of the IUD in horizontal section.

The IUD was detected between the rectum and the posterior uterus (Figures 3 and 4). The patient was hospitalised and combined antibiotherapy including gentamicin and clindamycin was planned. Appropriate intravenous fluid replacement was administered without oral intake. After preoperative evaluation, she was subjected to a laparotomy. Both gynaecology and general surgery teams were present at the time of the surgery.
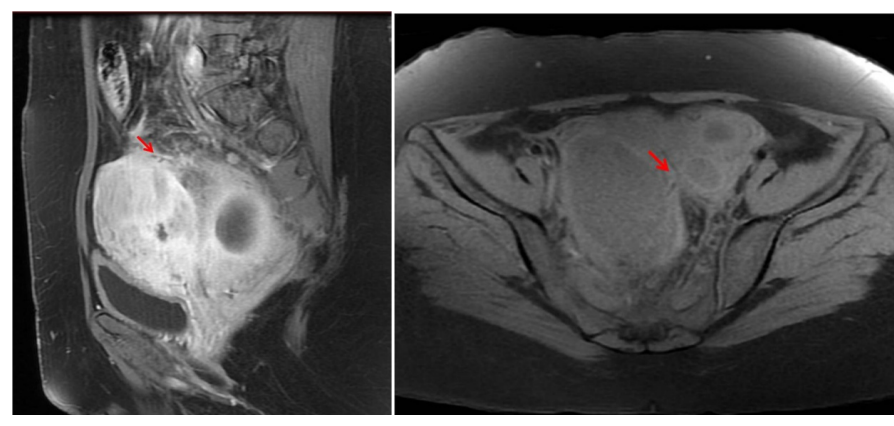

Figures 3 and 4. Image of the T-part of the IUD in vertical section and the irregular appearance of pelvic structures between the rectum and posterior uterus. A perforated IUD was detected between the uterus fundus and the rectum.

A frozen pelvis was the first intraoperative observational finding when we entered the peritoneum. The uterus, left ovary, sigmoid colon and rectum were organised as a phlegmon mass. Following sharp and blunt dissection, approximately $250 \mathrm{cc}$ of particulate abscess material was drained. Next, we performed a subtotal hysterectomy and left salphingooophorectomy, and we visualised the anterior wall of the rectum. The IUD was localised at the 
anterior wall of the rectosigmoid junction. A rectal tube was inserted intraoperatively, and following the administration of approximately $200 \mathrm{cc}$ of methylene blue solution through the rectal tube, we detected a leak at the insertion point of the IUD. Subsequently,the IUD was removed from the abdomen, and the fistula area was debrided and repaired with polyglactin sutures. A loop colostomy was performed in the ascending colon. After 10 days of followup, the patient was discharged without any complication. The patient consented to the publication of this case.

\section{Discussion}

IUDs may have side effects, such as pelvic pain, abnormal bleeding or vaginal discharge. Although uterine perforation can occur at the time of insertion, serious complications rarely occur. In a large cohort, uterine perforation risk was found to be six-fold higher in lactating women [3]. An immobile or retroverted uterus or a uterus with a myometrial defect may be classified as other patient-related risk factors. The experience of the responsible clinician is also important in the evaluation of risk factors and insertion technique.

Some clinicians re-evaluate patients 6 weeks after insertion because uterine perforation may occur after insertion. US is an adequate method to evaluate copper IUDs. If malpositioning of the IUD is detected in the borders of the uterus, hysteroscopy is the first choice of treatment. If an IUD is found outside the uterus, X-ray, computed tomography (CT) or MRI will provide more detailed information.

A perforated IUD can be grabbed by its string if it is recognised at the time of insertion, although such patients should be followed-up because of the risk of bleeding. On the other hand, removal of a migrated IUD requires a surgical approach. Over the past few decades, there is emerging data suggesting greater risk in surgery than in simply leaving the IUD [4]. However, removal of the IUD is recommended in modern practice. Treatment with antibiotics for pelvic inflammatory disease is also recommended [5]. The major concerns for perforated IUD include adhesion formation, bowel, bladder or vessel injuries and the associated consequences of these processes [6].

Patients should be evaluated as a whole with examinational, laboratory, imaging and clinical findings. Pelvic or whole abdominal pain, nausea, vomiting, inability to def- ecate and fever are the main symptoms for peritoneal irritation or bowel injury in a patient with a migrated IUD. US is a safe, feasible and non-invasive imaging method that can be used to visualise the uterus and the migrated IUD. However, a whole abdomen X-ray can be more helpful in detecting an IUD that is localised outside the pelvis. CT with oral and intravenous contrast is preferredfor detecting a bowel injury whereas MRI is preferred for identifying the relationship with soft tissue. Increased levels of inflammatory markers such as, WBC, C-RP and sedimentation rate, are frequently determined. However, bowel perforation and associated sepsis should be investigated in cases involving low levels of WBCs and platelets and impaired coagulation profile.

In cases where serious complications and organ perforation cannot be excluded, diagnostic laparoscopy is the preferred surgical option. Abdomen visualisation, IUD removal, intestinal resection and anastomosis or intracorporeal suturing are possible options in non-complicated cases with laparoscopy. The advantages of laparoscopy include reduced trauma to the tissues, intraabdominal adhesion formation and postoperative pain. However, re-laparoscopy and conversion to laparatomy or colostomy may be required in complicated cases [7]. Another minimallyinvasive option is colonoscopy, and this may represent a good alternative if the IUD is buried in the intestinal lumen or inside the intestinal wall. On the other hand, it may be difficult to remove the IUD if it has migrated to structures outside the intestine and may result in leakage of intestinal contents into the abdominal cavity [8]. Laparotomy is required if the problem cannot be solved with minimallyinvasive techniques.

Here, we present a case of a young woman with an IUD and its serious complications, eventually resulting in a laparotomy. The patient showed none of the risk factors for uterine perforation at the time of insertion and did not seek the guidance of a gynaecologist for IUD control. Therefore, we cannot definitely designate whether the IUD was in the peritoneal cavity for 3 years or if it perforated the uterus with chronical damage. In the management of this case, MRI revealed the uterine defect very well, although CT with contrast would be very helpful in detecting intestinal injury preoperatively. 
Rahim içi araç (RiA) migrasyonuna bağlı kolon perforasyonu: akut abdomenin cerrahi yönetimi

\section{Conclusion}

Serious IUD-related complications are not common and majority of these occur at the time of placement because ofuterine perforation. IUDs should only be inserted by experienced clinicians following careful evaluation for risk factors. However, IUDs should be evaluated by ultrasound to detect whether they are located in the endometrial cavity. Patients should regularly seek the guidance of a gynaecologist for IUD control. Removal of an IUD is suggested after the expiration date.

\section{Declaration of conflicting interests}

The author declared no conflicts of interest with respect to the authorship and/or publication of this article.

\section{References}

1. United Nations. World contraceptive use 2011. 2011. Available at:http://www.un.org/esa/population/publications/contraceptive2011/ contraceptive 2011. htm. Accessed February 8, 2013.

2. Heinemann K, Reed S, Moehner S, Minh TD. Risk of uterine perforation with levonorgestrel-releasing and copper intrauterine devices in the European Active Surveillance Study on Intrauterine Devices. Contraception 2015; 91:274.

3. Heinemann K, Reed S, Moehner S, Minh TD. Comparative contraceptive effectiveness of levonorgestrel-releasing and copper intrauterine devices: the European Active Surveillance Study for Intrauterine Devices. Contraception 2015;91(4):280-3.doi: 10.1016/j. contraception. 2015.01.011. Epub 2015 Jan 16.
4. Adoni A, Ben Chetrit A. The management of intrauterine devices following uterine perforation. Contraception 1991; 43:77.

5. Hatcher RA, Trussell J, Stewart F, et al. Contraceptive Technology, 19th ed, Ardent Media, Inc., New York 2007.

6. Vasquez P, Schreiber CA. The missing IUD. Contraception 2010; $82: 126$.

7. Chi E, Rosenfeld D, Sokol TP. Laparoscopic removal of an intrauterine device perforating the sigmoid colon: a case report and review of the literature. Am Surg 2005;71:1055-7.

8. Zeino MY, Wietfeldt ED, Advani V, Ahad S, Younkin C, Hassan I. Laparos-copic removal of a copper intrauterine device from the sigmoid colon. JSLS 2011;15:568-70.

Corresponding Author: Emre Günakan, Keçioren Training and Research Hospital, Department of Obstetrics and Gynecology, Pınarbası Mah. Sanatoryum Cad. Ardahan Sok. No:25, 06380, Keçioren, Ankara, Turkey.

E-mail: emreg43@hotmail.com 